\title{
INVENTARISASI DAN IDENTIFIKASI PATOGEN POTENSIAL YANG MENGINFEKSI IKAN RAINBOW (Melanotaenia sp.)
}

\author{
Lili Sholichah", Taukhid"), dan Gigih Setia Wibawa**) \\ *) Balai Penelitian dan Pengembangan Budidaya Ikan Hias \\ Jl. Perikanan No. 13, Pancoran Mas, Depok 16436 \\ E-mail: lili.bihatdepok@gmail.com \\ **) Balai Penelitian dan Pengembangan Budidaya Air Tawar \\ Jl. Sempur No. 1, Bogor 16154 \\ ***) Balai Besar Penelitian dan Pengembangan Budidaya Laut \\ Jl. Br. Gondol Kec. Gerokgak Kab. Buleleng, Kotak Pos 140, Singaraja, Bali 81101
}

(Naskah diterima: 8 Mei 2013; Disetujui publikasi: 10 Maret 2014)

\begin{abstract}
ABSTRAK
Pemeliharaan ikan rainbow (Melanotaenia sp.) di Balai Penelitian dan Pengembangan Budidaya Ikan Hias selalu terjadi kematian secara bertahap mulai calon induk hingga proses pemijahan. Hal ini terjadi berulang kali sehingga ketersediaan induk Melanotaenia sp. sangat terancam. Ikan ini berasal dari Papua yang diperoleh mengandalkan penangkapan di alam. Tujuan dari penelitian ini adalah untuk menginventarisir dan mengidentifikasi berbagai patogen (parasit, jamur, bakteri) potensial yang menginfeksi ikan rainbow yang dipelihara di dalam akuarium berukuran $50 \mathrm{~cm} \times 50 \mathrm{~cm} \times 50 \mathrm{~cm}$ dengan sistem aliran air stagnan. Tiga jenis rainbow yang dipelihara yaitu: rainbow Sungai Salawati, asal Sungai Sawiat, dan asal Danau Kurumoi. Setiap ikan masing-masing berjumlah 100 ekor dipelihara di akuarium dengan penambahan batu karang dan tanpa penambahan karang (kontrol) ke dalam akuarium. Ikan diberi pakan sekenyangnya berupa jentik nyamuk dan cacing rambut beku setiap pagi dan sore hari. Sampling dilakukan secara random sebulan sekali dan secara unrandom setiap ada kejadian ikan sakit. Gejala klinis ikan yang sakit sebagai berikut: ikan berenang di permukaan dan menggosok-gosokkan badan di dinding akuarium, nafsu makan berkurang, gerakan berputar-putar, warna memudar menjadi putih, penekanan warna hitam pada sirip punggung dan perut meningkat, pendarahan pada perut, lendir berlebihan dan sangat berbau, serta sisik berdiri/terbuka. Diagnosa dan deteksi penyakit awal berupa pengamatan parasit baik ektoparasit maupun endoparasit, pengamatan dan isolasi jamur pada media selektif jamur, dan isolasi bakteri dilakukan untuk mengetahui jenis-jenis patogen yang menginfeksi ketiga jenis ikan rainbow. Selanjutnya dilakukan uji histologi dan analisa DNA beberapa patogen. Hasil pengamatan diperoleh patogen berupa parasit (Ichthyophthirius sp., Dactylogyrus sp., Gyrodactylus sp., dan Trichodina sp.) dan bakteri (Aeromonas hydrophila, Acinetobacter sp., Lactobacillus sp., Bacillus sp., Arachnia sp., Haemophilus sp., Cardiobacterium sp., dan Enterobacter sp.) sedangkan jamur tidak ditemukan dalam penelitian ini.
\end{abstract}

KATA KUNCl: inventarisasi, identifikasi, patogen potensial, ikan rainbow

ABSTRACT: Inventory and identification of potential pathogens that infect rainbow fish (Melanotaenia sp.). By: Lili Sholichah, Taukhid, and Gigih Setia Wibawa

In the maintenance of rainbow fish (Melanotaenia sp.) at Research and Development Institute for Ornamental Fish Culture, the death fish always occur gradually begining from early matured fish to the spawning process. This happens over and over again 
so that the availability of Melanotaenia sp. parents are highly threatened. The fish comes from Papua which were obtained relying on catches in nature in. The purpose of this study was to inventory and identify the various pathogens (parasites, fungi, bacteria) that infects the potential rainbow fish reared in the aquarium measuring $50 \mathrm{~cm} \times 50 \mathrm{~cm} \times 50 \mathrm{~cm}$ with stagnant water flow sistem. The three species rainbow reared were rainbow Salawati River, originally from Sawiat River, and from Lake Kurumoi (treatment). Each fish has 100 individuals reared in the aquarium with the addition of coral reefs and without addition (control). The fish were given feed at satiation of mosquito larvae and frozen blood worms every morning and evening. Sampling was done randomly once a month and a unrandom every incident sick fish. Clinical symptoms of the sick fish as follows: fish swimming on the surface and rubbed his body against the wall aquarium, decreased appetite, whirling, the color fades to white, black emphasis on the dorsal and abdominal increases, bleeding in the stomach, excessive mucus and very odorless, and scales up/open. Diagnosis and an early disease detection were done in the form of observations of both ectoparasites and endoparasites. Observation and isolation on selective media mushroom fungus, and bacterial isolation were conducted to determine the types of pathogens that infect all three types of rainbow fish. Histological and DNA analysis of some pathogens were then conducted. The result showed that retrieved pathogenic form of the parasite (Ichthyophthirius sp., Dactylogyrus sp., Gyrodactylus sp., and Trichodina sp.) and bacteria (Aeromonas hydrophila, Acinetobacter sp., Lactobacillus sp., Bacillus sp., Arachnia sp., Haemophilus sp., Cardiobacterium sp., and Enterobacter sp.) while the fungus was not found in this study.

\section{KEYWORDS: inventory, identification, potential pathogens, rainbow fish}

\section{PENDAHULUAN}

Ikan pelangi (rainbow) merupakan salah satu ikan hias yang memiliki warna yang indah seperti pelangi sehingga memiliki nilai estetis dan nilai ekonomis yang tinggi. Terdapat 65 spesies ikan pelangi yang telah dideskripsi di kawasan daratan besar New Guinea dan Australia, dan 37 spesies di antaranya mendiami daratan Papua Indonesia (Sudarto et al., 2007). Bisnis ikan hias air tawar cukup baik perannya dalam memberi devisa pada negara, akan tetapi jika dibandingkan dengan kebutuhan ikan hias dunia nilainya masih relatif kecil. Kebutuhan pasar Uni Eropa dipasok oleh Singapura sebanyak $25 \%$, sedangkan Indonesia hanya memasok 9\%, padahal sebagian besar dari ikan yang dipasok oleh Singapura berasal dari Indonesia. Ikan hias air tawar merupakan produk hiburan yang sejak krisis moneter mempunyai nilai ekonomis yang makin nyata. Kondisi ini terjadi selain dari adanya dukungan pemerintah pada fasilitas transportasi, juga pada kualitas produk itu sendiri serta kurangnya perhatian terhadap pengembangan ikan hias menyebabkan ekspor ikan hias mengalami penurunan. Salah satu yang mempengaruhi kualitas ikan hias adalah adanya infeksi penyakit (Taufik, 2008). Ikan pelangi sangat rentan terhadap perubahan lingkungan dan habitat aslinya. Seiring dengan meningkatnya kegiatan logging yang berakibat pada degradasi habitat pada sungai-sungai karstik dan sebagian danau vulkanik menyebabkan kelestarian ikan pelangi menjadi terancam (Kadarusman et al., 2007). Genus Melanotaenia dari famili Melanotaenidae merupakan kelompok ikan yang terancam punah yang ditetapkan oleh International Union for Conservation Nature (IUCN) (Wargasasmita, 2004 dalam Kadarusman et al., 2007).

Penyakit didefinisikan sebagai suatu keadaan fisik, morfologi dan atau fungsi yang mengalami perubahan dari kondisi normal karena beberapa penyebab, yaitu penyebab internal (dari dalam tubuh ikan itu sendiri) dan eksternal (dari luar). Pada umumnya penyakit ikan disebabkan oleh penyakit eksternal yang bersifat patogen (serangan virus, jamur, bakteri, dan parasit). Proses budidaya ikan harus didukung berbagai aspek teknis seperti: genetika, reproduksi, lingkungan, dan penyakit. Apabila salah satu aspek ada yang kurang atau tidak terpenuhi maka proses budidaya tidak dapat dilaksanakan secara optimal (Yuasa et al., 2002). Ikan merupakan salah satu hewan air yang selalu bersentuhan dengan lingkungan perairan sehingga mudah terinfeksi patogen melalui air. Infeksi bakteri dan parasit tidak terjadi pada hewan darat melalui perantara udara, namun pada ikan sering terjadi 
melalui air. Pada budidaya, air tidak hanya sebagai tempat hidup bagi ikan, tapi juga sebagai perantara bagi patogen.

Agen penyebab penyakit infeksius dapat disebabkan oleh organisme patogen dari golongan bakteri, parasit, jamur dan virus (Dogie et al., 1958; Yuasa et al., 2002; Untergasser, 1989). Patogen parasitik jarang mengakibatkan wabah penyakit yang sporadis (Hawking et al., 2006; Piazza et al., 2006; Lewbart, 2008; Alvarez, 2009; Lewbart, 2009; Weaver, 2009), namun pada intensitas penyerangan yang tinggi dapat menimbulkan kerugian ekonomi yang signifikan, oleh karena dapat mengakibatkan kematian. Di samping itu, infeksi parasit juga dapat menurunkan bobot, penampilan serta menurunkan ketahanan tubuh ikan dan akan dimanfaatkan sebagai tempat masuk bagi penginfeksi sekunder oleh patogen lain seperti jamur dan bakteri Jones, 2008; Betty, 2009; Noga, 2000).

Beberapa jenis bakteri yang umum ditemukan pada ikan hias yaitu Aeromonas sp., Edwardsiella tarda, Yersinia sp., Flavobacterium sp., dan Mycobacterium sp., tetapi infeksi dominan oleh Aeromonas hydrophila, sedangkan parasit di antaranya adalah dari kelompok Digenea (metacercaria dari Ascocotyle), Monogenea, Diniflagellida (Piscinoodinium pillulare), Chiliophora (Trichodina maculata, Ichtyophthirius multifiliis, Chilodonella sp.), Nematoda (Camallanus maculatus), dan Crustacea (Lernaea cyprinacea, Argulus). (Hawking et al., 2006; Piazza et al., 2006; Lewbart, 2008; Musa et al., 2008; Alvarez, 2009; Graham, 2009; Lewbart, 2009; Weaver, 2009).

Penelitian ini bertujuan untuk menginventarisasi dan mengidentifikasi patogen-patogen yang menginfeksi ikan rainbow (Melanotaenia sp.) selama pemeliharaan dengan dan tanpa penambahan batu karang ke dalam akuarium.

\section{BAHAN DAN METODE}

\section{Pemeliharaan Ikan Rainbow}

Ikan uji dipelihara dalam akuarium berukuran $50 \mathrm{~cm} \times 50 \mathrm{~cm} \times 50 \mathrm{~cm}$ dengan sistem pengaliran air stagnan. Tujuan dibuat stagnan untuk mencegah bila terjadi infeksi patogen agat tidak menular ke akuarium yang lainnya. Dari hasil survai langsung ke habitat asli di Papua (dilakukan oleh Tim Ekspedisi Rainbow, kerja sama Balitbang ikan hias, Depok dengan IRD Perancis) diperoleh informasi mengenai syarat hidup ikan rainbow, salah satu yang paling penting adalah $\mathrm{pH}$ cenderung basa $(>7,5)$. Untuk mengkondisikan akuarium dengan $\mathrm{pH}$ target maka ditambahkan karang hingga $\mathrm{pH}$ stabil > 7,5 dengan cara menaruh 1 $\mathrm{kg}$ batu karang yang dibungkus jaring-jaring plastik dan diletakkan di dasar akuarium.

Tiga jenis rainbow yang dipelihara sebagai perlakuan yaitu rainbow asal Sungai Salawati (SL), Sungai Sawiat (SW), dan Danau Kurumoi (KM) masing-masing berjumlah 100 ekor dengan penambahan batu karang ke dalam akuarium dan sebagai kontrol tanpa penambahan batu karang. Penamaan "Sungai Salawati", "Sungai Sawiat", dan "Danau Kurumoi" didasarkan pada nama sungai tempat penangkapan ikan ini. Ikan diberi pakan dengan metode pemberian pakan tidak terbatas (ad libitum) berupa jentik nyamuk (Culex sp.) dan cacing darah beku (frozen bloodworm) setiap pagi dan sore hari.

\section{Sampling}

Metode sampling dilakukan secara random sebulan sekali dan secara unrandom setiap ada kejadian ikan sakit. Random diambil dari masing-masing wadah pemeliharaan tiap-tiap jenis rainbow asal Sungai Salawati (SL), Sungai Sawiat (SW), dan Danau Kurumoi (KM) dan diambil ikan yang sakit parah, agak parah, dan yang tampak sehat. Sedangkan sampling unrandom dilakukan setiap kali ada kejadian ikan yang sakit.

\section{Pengamatan dan Pencatatan Gejala Klinis}

Gejala klinis ikan yang sakit sebagai berikut: ikan berenang di permukaan dan menggosok-gosokkan badan di dinding akuarium, nafsu makan berkurang, gerakan berputarputar, warna memudar menjadi putih, penekanan warna hitam pada sirip punggung dan perut meningkat, pendarahan pada perut, mucus berlebihan, dan sangat berbau, serta sisik berdiri/terbuka. Respon terhadap pakan yang diberikan juga dapat diamati dan selanjutnya dapat dihitung dan ditentukan persentase prevalensi yang terjadi selama pemeliharaan.

\section{Identifikasi Patogen}

Bahan dan alat yang digunakan untuk mengidentifikasi patogen antara lain: dissecting kit, mikroskop dengan objective 10, 20, $40, \& 100 X$, petridisk, slide glass \& cover glass, autoclave, refrigerator, inkubator, hot plates, 
stir plates, timbangan analitik, erlenmeyer, gelas ukur, mikropipet, pippet dan bulb, marker, kertas label, kamera digital, buku panduan identifikasi parasit; medium agar TSA, TSB, BHI, media selektif untuk Aeromonas (RS/ Rimler-Shotts), media selektif untuk Mycobacterium (Shouten agar), media selektif untuk inokulasi jamur (Gypox), Salin 0,845\% steril, PBS (phosphate buffered salane/larutan penyangga), akuades, Davidson's AFA dan $10 \%$ buffered formalin.

\section{Pengamatan Parasit}

Langkah berikutnya adalah pengamatan parasit baik terhadap parasit eksternal maupun parasit internal, baik dari kelompok protozoa, helminth, maupun krustasea. Ektoparasit yang besar dapat langsung diidentifikasi karena dapat dilihat dengan mata telanjang, sedangkan endoparasit diamati di bawah mikroskop. Insang dan sirip diamati juga.

Pengamatan ektoparasit dilakukan dari kulit (lendir), sirip dan insang. Sampel diambil dengan cara membuat sediaan segar yang kemudian diamati dengan mikroskop. Diagnosa parasit dilakukan secara morfologi. Pada waktu yang sama dilakukan pengamatan kondisi ikan. Umumnya setiap parasit mempunyai siklus hidup yang rumit, yang merupakan kunci penting pengobatan ikan yang terserang parasit. Studi siklus parasit sangat penting untuk menentukan tindakan penanganan yang lengkap. Uji coba infeksi dengan parasit umumnya sulit dilakukan karena parasit tidak dapat diinkubasi atau ditumbuhkan dan dipelihara pada media buatan (Yuasa et al., 2002).

\section{Isolasi Bakteri}

Ikan dibedah untuk membuka rongga perut dengan menggunakan dissecting kits. Pengamatan meliputi aspek-aspek dari bagian organ internal yaitu ukuran dan warna, ada tidaknya pendarahan dan bintik-bintik putih, ada tidaknya massa air di rongga perut atau usus. Isolasi bakteri dari hati, ginjal, dan limpa menggunakan media TSA dan BHI. Purifikasi (pemurnian) dilakukan hingga tiga kali atau sampai mendapatkan koloni murni yang terpisah dan selanjutnya diidentifikasi dengan uji fisiologi dan biokimia meliputi pewarnaan gram, motilitas, sitokrom oksidase, oksidatif fermentative (O-F), sensitivitas terhadap novobiosin menurut metode Amos (1985), Frerich \& Millar (1993), Cowan (1974), dan Austin \&
Austin (1999). Tes terhadap tiap jenis bakeri dilakukan secara duplo dan bila hasilnya berbeda dilakukan triplo.

\section{Persiapan Sampel untuk PCR}

Pelet bakteri diperoleh dengan cara sentrifugasi pada $12000 \times$ g selama sepuluh menit kemudian diresuspensi kembali dengan 400 $\mu \mathrm{L}$ RNAse free water dan dipanaskan pada suhu $98^{\circ} \mathrm{C}$ selama sepuluh menit sambil sesekali divortex. DNA bakteri diperoleh dengan sentrifugasi pada $8000 \times$ g selama sepuluh menit (Gardenia et al., 2010).

\section{Pengamatan Histologi}

Ikan sampel difiksasi dalam larutan formalin $10 \%$ berpenyangga pospat untuk pemeriksaan histopatologi. Pengamatan histopatologi dilakukan menggunakan Metode Gurr (1956) yang terdiri atas fixation, cleaning, embedding, cutting, dan staining dengan hematoxylin dan eosin. Setelah itu dibaca mikroskopis dengan pembesaran 20x.

\section{Pengamatan Kualitas Air}

Analisis kualitas air dilakukan setiap bulan meliputi parameter: suhu, $\mathrm{pH}$, kandungan oksigen terlarut, dan konduktivitas.

\section{Analisis Data}

Data yang diperoleh yaitu: inventarisasi dan identifikasi patogen, prevalensi, histopatologi, amplifikasi PCR menggunakan primer spesifik AeroFd/AeroRs dan kualitas air dianalisis secara deskriptif dalam bentuk tabel, gambar, dan histogram.

\section{HASIL DAN BAHASAN}

\section{Hasil Inventarisasi dan Identifikasi Patogen}

Pemeriksaan tubuh bagian eksternal dimulai dengan mengamati perubahan pada kulit, sisik, sirip, insang serta mata ikan. Hasil yang paling mencolok adalah ditemukan adanya lesi dan atau borok pada bagian perut tepat di bawah sirip dan pada beberapa ikan yang sakit ditemukan selaput keruh pada daerah mata (Gambar 1). Perubahan klinis lainnya berupa warna memudar menjadi putih, penekanan warna hitam pada sirip punggung dan perut meningkat, lendir berlebihan dan sangat berbau, serta sisik berdiri mudah rontok. Insang berwarna pucat dan geripis di 


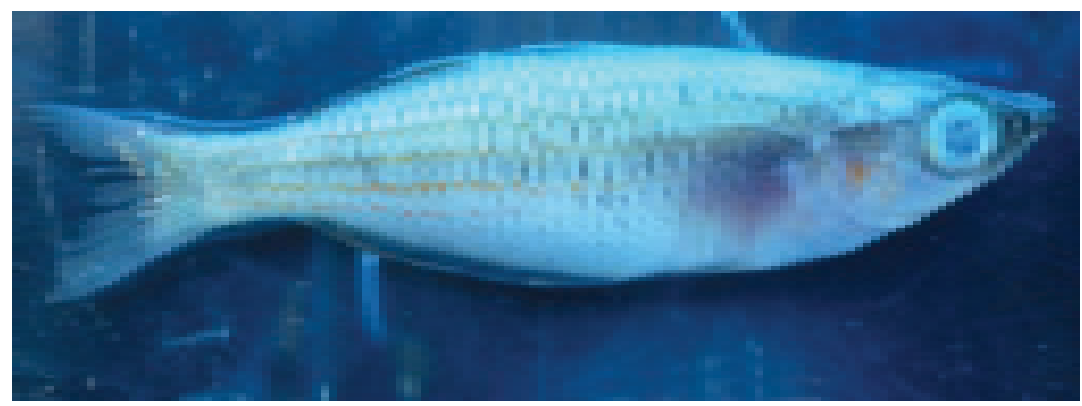

Gambar 1. Ikan rainbow Salawati yang sakit

Figures 1. Infected Salawati rainbow fish

sebagian lamela sekunder insang. Pemeriksaan tubuh bagian internal dimulai dengan pembedahan ikan mulai dari anus, ventral ke depan, lanjut sampai daging yang menutupi perut terbuka. Hasilnya adalah terdapat pendarahan pada organ hati dan warna organ dalam lebih pucat dibandingkan normalnya. Tidak ditemukan massa air pada usus ataupun perlekatan antar organ.

Patogen yang berhasil diidentifikasi dari ikan rainbow berupa patogen parasitik dan bakterial namun sama sekali tidak ditemukan patogen fungal atau jamur. Ada empat genus parasit yang diinventarisasi terdiri atas: Ichthyophthirius sp., Dactylogyrus sp., Gyrodactylus sp., dan Trichodina sp. Ada kesamaan jenis parasit yang ditemukan antara kontrol Salawati (KSL) dengan Salawati (SL) yaitu infestasi parasit Ichthyophthirius sp., Dactylogyrus sp., Gyrodactylus sp.; begitu pula dengan infestasi parasit Trichodina sp. yang ditemukan hanya pada kontrol Sawiat (KSW) dan Sawiat (SW) saja; sedangkan pada kontrol Kurumoi (KKM) dan Kurumoi (KM) ditemukan infestasi parasit Dactylogyrus sp. dan Gyrodactylus sp.

Inventarisasi dan identifikasi patogenpatogen yang menginfeksi ikan rainbow dapat dilihat pada Tabel 1. Bakteri Aeromonas ditemukan pada semua kontrol baik KSL, KSW, dan KKM tetapi tidak ditemukan pada perlakuan SL, SW, KM meskipun banyak bakteri yang teridentifikasi dari akuarium perlakuan. Misal bakteri Acinetobacter sp. berhasil diidentifikasi dari perlakuan SL; bakteri Lactobacillus sp., Bacillus sp., Haemophilus sp., dan Arachnia sp. dapat diinventarisasi dari perlakuan SW; sedangkan Cardiobacterium sp., Acinetobacter sp., dan Enterobacter sp. ditemukan pada perlakuan KM.
Perbedaan yang sangat nyata ditemukan antara patogen parasitik dengan bakterial. Semua parasit yang teridentifikasi jenisnya sama untuk masing-masing jenis ikan rainbow yang dipelihara baik itu kontrol maupun perlakuan meskipun jenis parasitnya berbedabeda untuk tiap jenis ikan. Berbeda halnya dengan patogen bakterial, antara kelompok kontrol dengan kelompok perlakuan didapatkan jenis bakteri yang berbeda. Pada semua kontrol ditemukan bakteri Aeromonas tetapi Aeromonas ini sama sekali tidak ditemukan pada kelompok perlakuan maupun masingmasing perlakuan.

Parasit dari kelompok protozoa yang teridentifikasi di antaranya Trichodina sp. dan Ichthyophthirius multifiliis (Tabel 2). Trichodina merupakan protozoa bercilia yang menyebabkan iritasi pada organ yang terinfeksi. Trichodina dan Ichthyophthirius ditemukan pada kulit ikan. Pada kejadian yang sangat serius, infeksi Trichodina akan mengakibatkan luka borok (Smith \& Schwart, 2009). "Ich" atau "white spot disease" disebabkan oleh infeksi Ichthyophthirius multifiliis sering terjadi baik pada ikan hias maupun pada ikan konsumsi (Floyd \& Reed, 1991). Ichthyophthirius multifiliis adalah jenis parasit yang digolongkan ke dalam phylum Protozoa, sub phylum Ciliophora, kelas Ciliata, sub kelas Holotrichia, Ordo Hymenostomatida, famili Ophryoglenia dan genus Ichthyophthirius multifiliis (Hoffman, 1967). Ikan yang terserang parasit ini memperlihatkan gejala sebagai berikut: produksi lendir yang berlebihan, adanya bintik-bintik putih (white spot), frekuensi pernafasan meningkat, dan pertumbuhan terhambat. Hal yang paling penting dalam diagnosa adalah pertimbangan serangan parasit, karena tingkat serangannya tergantung pada jumlah parasit. 
Tabel 1. Inventarisasi dan identifikasi patogen-patogen yang menginfeksi ikan rainbow Table 1. Inventaritation and identification of pathogens that infect rainbow fish

\begin{tabular}{|c|c|c|c|}
\hline $\begin{array}{c}\text { Perlakuan } \\
\text { Treatment }\end{array}$ & $\begin{array}{l}\text { Bakt eri } \\
\text { Bacteria }\end{array}$ & $\begin{array}{l}\text { Parasit } \\
\text { Parasite }\end{array}$ & $\begin{array}{l}\text { Jamur } \\
\text { Fungi }\end{array}$ \\
\hline $\begin{array}{l}\text { Kontrol Salawati } \\
\text { Control of Salawati }\end{array}$ & Aeromonas hydrophila & $\begin{array}{l}\text { Ichthyopthirius sp. } \\
\text { Dactylogyrus sp. } \\
\text { Gyrodactylus sp. }\end{array}$ & - \\
\hline $\begin{array}{l}\text { Kontrol Sawiat } \\
\text { Control of Sawiat }\end{array}$ & Aeromonas hydrophila & Trichodina sp. & - \\
\hline $\begin{array}{l}\text { Kontrol Kurumoi } \\
\text { Control of Kurumoi }\end{array}$ & Aeromonas hydrophila & $\begin{array}{l}\text { Dactylogyrus sp. } \\
\text { Gyrodactylus sp. }\end{array}$ & - \\
\hline Salawati & Acinetobacter sp. & $\begin{array}{l}\text { Ichthyopthirius sp. } \\
\text { Dactylogyrus sp. } \\
\text { Gyrodactylus sp. }\end{array}$ & - \\
\hline Sawiat & $\begin{array}{l}\text { Lactobacillus sp. } \\
\text { Bacillus sp. } \\
\text { Haemophilus sp. } \\
\text { Arachnia sp. }\end{array}$ & Trichodina sp. & - \\
\hline Kurumoi & $\begin{array}{l}\text { Cardiobacterium sp. } \\
\text { Acinetobacter sp. } \\
\text { Enterobacteria sp. }\end{array}$ & $\begin{array}{l}\text { Dactylogyrus sp. } \\
\text { Gyrodactylus sp. }\end{array}$ & - \\
\hline
\end{tabular}

Parasit monogenea yang teridentifikasi adalah Gyrodatylus sp. dan Dactylogyrus sp. Dactylogyrus lebih dikenal juga dengan istilah parasit insang, karena parasit ini hanya akan teramati pada insang. Sedangkan Gyrodactylus terdapat pada kulit dan sirip. Morbiditas dan mortalitas bisa terjadi disebabkan oleh parasit ini. Penyebaran bisa terjadi dengan adanya kontak langsung antar ikan (Reed et al., 1996). Semua parasit yang teridentifikasi pada Tabel 2 ditemukan pada pengamatan mikroskopis dengan perbesaran 100x. Isolat bakteri diambil dari hati, ginjal, dan luka, bakteri yang teridentifikasi adalah Aeromonas hydrophila yang telah banyak dilaporkan dapat menginfeksi ikan air tawar di Indonesia (mas, nila, dan patin) (Yuasa et al., 2002).

\section{Prevalensi}

Prevalensi infestasi parasit dalam persen atau derajat infeksi per satuan waktu (pada penelitian ini jumlah ikan masing-masing 50 ekor yang dipelihara selama tujuh bulan) adalah $100 \%$ pada KSL dan $12 \%$ pada SL, $58 \%$ pada KSW, dan $18 \%$ pada SW, serta 34\% pada KKM dan 6\% pada KM dapat dilihat pada Ta- bel 3. Nilai prevalensi pada semua kelompok kontrol lebih tinggi dibandingkan kelompok perlakuan. Kemungkinan besar sangat dipengaruhi oleh penambahan batu karang ke dalam air pemeliharaan. Dengan penambahan batu karang, $\mathrm{pH}$ air menjadi lebih tinggi cenderung basa pada kisaran 7,75-8,85 dibandingkan kontrol yang tanpa penambahan batu karang $\mathrm{pH}$ pada kisaran 6,90-7,00. Ketahanan tubuh ikan rainbow lebih tinggi dan lebih kuat dengan mengkondisikannya pada $\mathrm{pH}$ yang cenderung basa, hal ini dibuktikan dengan prevalensi yang lebih rendah.

\section{Histopatologi Jaringan}

Organ ginjal, insang, kulit, dan hati dijadikan organ target untuk pengamatan histologi karena ginjal, insang, dan kulit adalah bagian penting dari sistem ekskresi dan sistem osmoregulasi pada ikan. Sedangkan fungsi hati adalah untuk menyaring semua sari makanan dan membuang semua racun dalam tubuh ikan.

Pada pemeriksaan ginjal (Gambar 2A) warna ginjal merah kecoklatan nampak gelap. Selain itu secara mikroskopis tampak melanomakrofag (kumpulan melanin) di antara tubu- 
Tabel 2. Klasifikasi, morfologi, dan organ target infeksi parasit pada ikan rainbow

Table 2. Classification, morphological and targeted organ of parasitic infection in rainbow

\begin{tabular}{|c|c|c|c|c|}
\hline $\begin{array}{l}\text { Spesies } \\
\text { Species }\end{array}$ & $\begin{array}{l}\text { Klasifikasi } \\
\text { Classification }\end{array}$ & $\begin{array}{c}\text { Morfologi } \\
\text { Morphological }\end{array}$ & $\begin{array}{l}\text { Inang } \\
\text { Host }\end{array}$ & $\begin{array}{c}\text { Organ target } \\
\text { Targeted } \\
\text { organ }\end{array}$ \\
\hline $\begin{array}{l}\text { Ichthyophthirius } \\
\text { multifiliis (proto- } \\
\text { zoa bersiliata) } \\
\text { ciliated protozoa }\end{array}$ & $\begin{array}{l}\text { Protozoa Ciliata } \\
\text { Haolotrica } \\
\text { Hymenostomatida }\end{array}$ & $\begin{array}{l}\text { Berbentuk bundar } \\
\text { sampai oval, ber- } \\
\text { silia (Round to oval, } \\
\text { ciliated) }\end{array}$ & $\begin{array}{l}\text { Rainbow asal } \\
\text { Sungai Salawati } \\
\text { (SL) (Rainbow } \\
\text { from Salawati } \\
\text { River) }\end{array}$ & Kulit (Skin) \\
\hline $\begin{array}{l}\text { Trichodina sp. } \\
\text { (protozoa } \\
\text { bersiliata) } \\
\text { ciliated protozoa }\end{array}$ & $\begin{array}{l}\text { Protozoa Ciliata } \\
\text { Spirotricha } \\
\text { Peritricha }\end{array}$ & $\begin{array}{l}\text { Berbentuk se perti } \\
\text { piring/cawan, } \\
\text { diameter } \pm 50 \mu \mathrm{m}, \\
\text { memiliki silia di } \\
\text { sekelilingnya } \\
\text { Shaped like a } \\
\text { dish/pan, } \pm 50 \mu \mathrm{m} \\
\text { diameter, have } \\
\text { cilia around }\end{array}$ & $\begin{array}{l}\text { Rainbow asal } \\
\text { Sungai Sawiat } \\
\text { (SW) (Rainbow } \\
\text { from Sawiat } \\
\text { River) }\end{array}$ & Kulit (Skin) \\
\hline $\begin{array}{l}\text { Dactylogyrus sp. } \\
\text { (trematoda } \\
\text { monogenetik) } \\
\text { trematoda } \\
\text { monogenetic }\end{array}$ & $\begin{array}{l}\text { Platyhelminthes } \\
\text { Trematoda } \\
\text { Monogenea }\end{array}$ & $\begin{array}{l}\text { Berbentuk meman- } \\
\text { jang, panjang } \pm 0,3- \\
1,0 \mathrm{~mm} \text {, me miliki } \\
\text { jangkar pada ujung } \\
\text { posterior dan } 2 \\
\text { pasang bintik mata } \\
\text { pada ujung anterior } \\
\text { Elongated, } \pm 0.3-1.0 \\
\mathrm{~mm} \text { long, having an } \\
\text { anchor at the end of } \\
\text { posterior and } 2 \\
\text { pairs of eye spots at } \\
\text { the end of anterior }\end{array}$ & $\begin{array}{l}\text { Rainbow asal } \\
\text { Sungai Salawati } \\
\text { (SL) dan } \\
\text { Rainbow asal } \\
\text { Danau Kurumoi } \\
\text { (KM) (Rainbow } \\
\text { from Salawati } \\
\text { and Kurumoi) }\end{array}$ & Insang (Gill) \\
\hline $\begin{array}{l}\text { Gyrodactylus sp. } \\
\text { (trematoda } \\
\text { monogenetik) } \\
\text { trematoda } \\
\text { monogenetic }\end{array}$ & $\begin{array}{l}\text { Platy helminthes } \\
\text { Trematoda } \\
\text { Monogenea }\end{array}$ & $\begin{array}{l}\text { Berbentuk meman- } \\
\text { jang, panjang } \pm 0,3- \\
1,0 \mathrm{~mm} \text {, me miliki } \\
\text { jangkar pada ujung } \\
\text { poste rior tapi tidak } \\
\text { terdapat bintik mata } \\
\text { dan me mpunyai anak } \\
\text { dalam tubuh } \\
\text { Elongated, } \pm 0.3-1.0 \\
\text { mm long, having an } \\
\text { anchor at the end of } \\
\text { posterior but there } \\
\text { is no eye spots and } \\
\text { have a child in the } \\
\text { body }\end{array}$ & $\begin{array}{l}\text { SL } \\
\text { SW } \\
\text { KM }\end{array}$ & $\begin{array}{l}\text { Kulit (Skin) } \\
\text { Sirip (Fin) }\end{array}$ \\
\hline
\end{tabular}


Tabel 3. Prevalensi infestasi parasit pada ikan rainbow

Table 3. Prevalence of parasites infestation in rainbowfish

\begin{tabular}{|c|c|c|c|}
\hline $\begin{array}{l}\text { Perlakuan } \\
\text { Treatment }\end{array}$ & $\begin{array}{l}\text { Ikan terinfeksi } \\
\text { Infected fishes }\end{array}$ & $\begin{array}{l}\text { Total ikan } \\
\text { Total fishes }\end{array}$ & $\begin{array}{c}\text { Prevalensi } \\
\text { Prevalence (\%) }\end{array}$ \\
\hline Kontrol Salawati (Control of Salawati) & 50 & 50 & 100 \\
\hline Kontrol Sawiat (Control of Sawiat) & 29 & 50 & 58 \\
\hline Kontrol Kurumoi (Control of Kurumoi) & 17 & 50 & 34 \\
\hline Salawati & 6 & 50 & 12 \\
\hline Sawiat & 9 & 50 & 18 \\
\hline Kurumoi & 3 & 50 & 6 \\
\hline Total & 114 & 300 & 38 \\
\hline
\end{tabular}

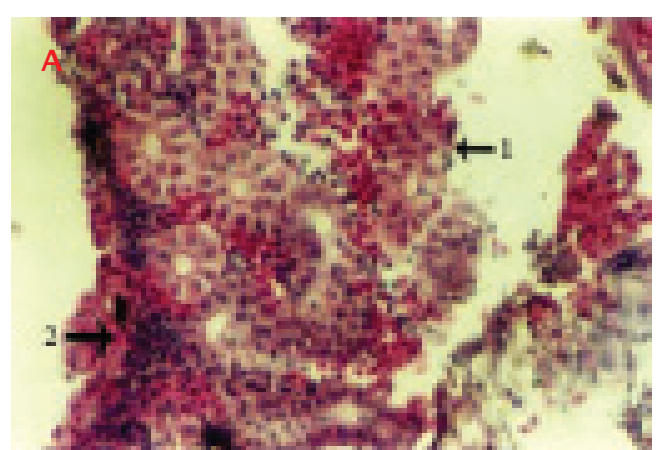

Ginjal (Ren) (H\&E,200x)

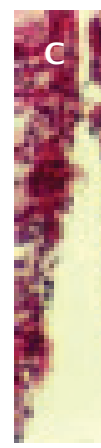

Insang (Gill) (H\&E,200x)

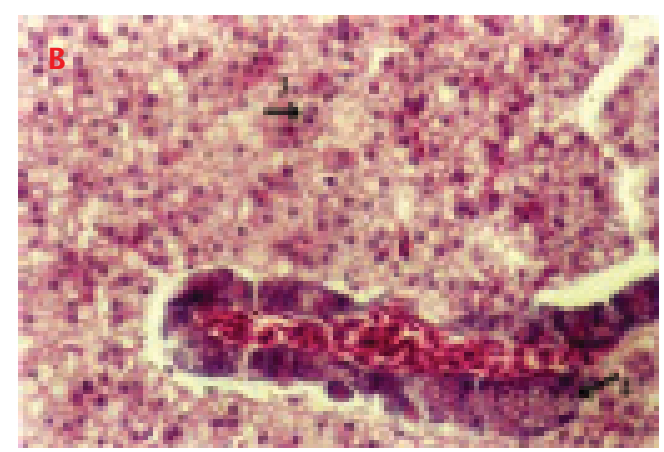

Hati (Hepar) (H\&E,200x)

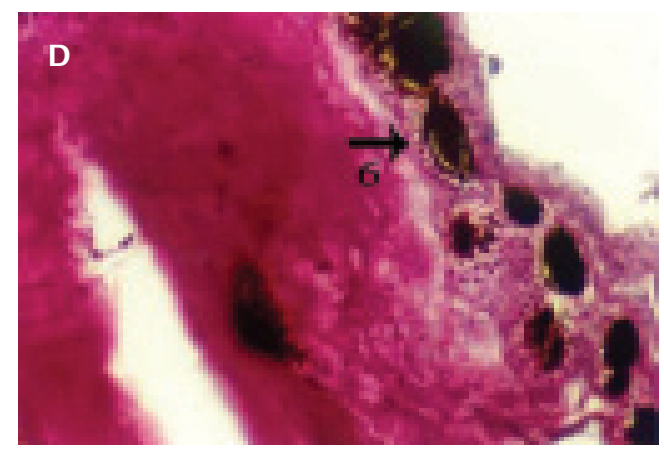

Kulit (Skin) (H\&E,200x)

Keterangan (Note):

1. Melanomakrofag, 2. Kongesti, 3. Nekrosis, 4. Vakuolisasi, 5. Fusi, 6. Infestasi parasit

1. Melanomacrophag, 2. Congestion, 3. Necrosis, 4. Vacuolisation, 5. Fusion, 6. Parasitic infestation

Gambar 2. Histologi jaringan yang diambil dari organ ginjal, hati, insang, dan kulit dengan pewarnaan haematoxilin dan eosin dengan pembesaran 200x (H\&E, 200x)

Figure 2. Histology of tissue taken from the kidney, liver, gill, and skin with haematoxilin and eosin staining at 200x magnification (H\&E, 200x) 
lus ginjal. Ini menunjukkan bahwa ikan yang dinekropsi menunjukkan gejala adanya infeksi. Hal tersebut diperkuat dengan kondisi ginjal yang membengkak. Selain itu, terdapat kongesti dan nekrosis pada sel-sel ginjal. Pada organ hati (Gambar 2B) terdapat nekrosis, banyak sel yang membesar, banyak sel yang fusi, dan terjadi vakuolisasi. Organ insang (Gambar 2C) tampak sangat parah di mana terjadi kongesti dan fusi lamela sekunder sehingga mengganggu pernafasan sedangkan pada kulit (Gambar 2D) tampak nodul-nodul hitam pada jaringan kulit yang merupakan bentuk dari infestasi parasit di kulit (Takashima \& Hibiya, 1995).

\section{Amplifikasi PCR}

Untuk menguatkan hasil bahwa ikan tersebut terinfeksi oleh bakteri seperti yang teridentifikasi secara morfologi dan biokimia adalah Aeromonas hydrophila maka dilakukan amplifikasi PCR menggunakan primer spesifik AeroFd/AeroRs dengan berat molekul 209 bp (Pollard et al., 1990) seperti pada Gambar 3.

Salah satu sampel yang diamplifikasi yaitu sampel pada lane 3 menunjukkan adanya infeksi bakteri Aeromonas hydrophila dibuktikan dengan munculnya band yang sama seperti pada Gambar 3. Ikan uji yang positif terinfeksi aeromonas adalah sampel B.2.1 dengan gejala klinis yang paling mencolok adalah ditemukan adanya lesi dan atau borok pada bagian perut tepat di bawah sirip, selaput keruh pada daerah mata, warna memudar menjadi putih, penekanan warna hitam pada sirip punggung dan perut meningkat, lendir berlebihan dan sangat berbau, serta sisik berdiri mudah rontok. Insang berwarna pucat dan geripis di sebagian lamela sekunder insang.

Dalam Aoki (1999), bahwa bakteri Aeromonas hydrophila pada media nutrien agar koloni bakteri ditemukan berwarna krem, bentuk bundar dan cembung, oksidase sitokrom dan reaksi katalase positif. Mikroskopis berbentuk batang dengan diameter 0,3 $1,0 \mu \mathrm{m}$ dan panjang 1,0-3,5 $\mu \mathrm{m}$. Bersifat gram negatif, fakultatif aerobik, tidak berspora, dan motil.

\section{Hasil Analisis Kualitas Air}

Parameter kimia yang diukur selama pemeliharaan ikan rainbow di dalam akuarium dengan pengairan stagnan meliputi: suhu, $\mathrm{pH}$, kandungan oksigen terlarut, dan konduktivitas dapat dilihat pada Tabel 4.

Hasil pengamatan kualitas air pemeliharaan ikan rainbow di dalam akuarium baik dengan penambahan dan tanpa penambahan batu karang menunjukkan kisaran nilai masih dalam kriteria yang layak bagi kehidupan ikan pelangi (Tabel 4). Ikan pelangi di Papua dijumpai di tepi

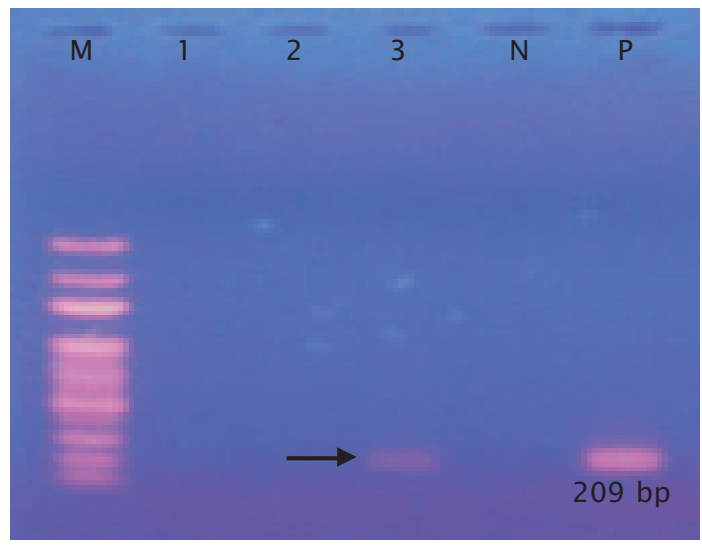

Keterangan (Note):

$\mathrm{M}=$ Marker; lane 1 = Sampel C.4.1; lane 2 =Sampel RS; lane 3 =Sampel B.2.1; $\mathrm{N}=$ Kontrol negatif; dan $\mathrm{P}=$ Kontrol positif $(M=$ Marker; lane $1=$ Sample C.4.1; lane $2=$ Sample RS; lane 3 = Sample B.2.1; $N$ = Negative control; and P = Positive control)

Gambar 3. Hasil amplifikasi DNA bakteri dengan PCR

Figure 3. The results of DNA bacterial by PCR amplification 
Tabel 4. Data kualitas air selama pemeliharaan ikan rainbow di akuarium stagnan

Table 4. Water quality data for rainbow fish in a stagnant aquarium maintenance

\begin{tabular}{lcccc}
\hline \multicolumn{1}{c}{$\begin{array}{c}\text { Perlakuan } \\
\text { Treatment }\end{array}$} & $\begin{array}{c}\text { Suhu } \\
\text { Temperature }\left({ }^{\circ} \mathbf{C}\right)\end{array}$ & $\mathbf{p H}$ & $\begin{array}{c}\text { DO } \\
(\mathbf{m g} / \mathrm{L})\end{array}$ & $\begin{array}{c}\text { Konduktivitas } \\
\text { Conductivity }(\boldsymbol{\mu S})\end{array}$ \\
\hline $\begin{array}{l}\text { Kontrol Salawati } \\
\text { Control of Salawati }\end{array}$ & $25.8-28.5$ & $6.91-7.00$ & $5.57-5.93$ & $155.5-169.0$ \\
$\begin{array}{l}\text { Kontrol Sawiat } \\
\text { Control of Sawiat }\end{array}$ & $25.8-28.1$ & $6.91-7.00$ & $5.57-5.93$ & $158.2-165.3$ \\
$\begin{array}{l}\text { Kontrol Kurumoi } \\
\text { Control of Kurumoi }\end{array}$ & $25.8-28.0$ & $6.91-7.00$ & $5.57-5.93$ & $157.6-169.9$ \\
$\begin{array}{l}\text { Salawati } \\
\text { Sawiat }\end{array}$ & $25.8-27.7$ & $7.75-7.81$ & $6.71-6.91$ & $179.9-214.0$ \\
Kurumoi & $25.8-27.8$ & $7.75-7.85$ & $6.75-6.90$ & $176.1-203.0$ \\
\hline & $25.8-28.5$ & $7.80-8.00$ & $6.69-6.87$ & $179.1-215.8$ \\
\hline
\end{tabular}

danau dan sungai dengan suhu $29^{\circ} \mathrm{C}-32^{\circ} \mathrm{C}$ serta nilai $\mathrm{pH}$ di permukaan berkisar 6.2-6.8 (Allen,1985 dalam Sudarto \& Nur, 2008). Menurut Kadarusman et al. (2007), ikan pelangi dapat ditemui pada dua habitat (danau dan sungai) dengan karakteristik habitat yang beragam namun umumnya menyukai aliran sungai dengan kandungan kalsium yang tinggi, suhu berkisar antara $25^{\circ} \mathrm{C}-26^{\circ} \mathrm{C}$ dan konduktivitas sekitar $300 \mu \mathrm{S}$.

\section{KESIMPULAN DAN SARAN}

Patogen yang berhasil diidentifikasi dan diinventarisasi pada penelitian ini terdiri atas patogen parasitik dan patogen bakterial. Jenisjenis parasit terdiri atas: Trichodina sp. yang terdapat pada kulit, Ichthyophthirius multifiliis juga terdapat pada kulit, Dactylogyrus sp. yang ditemukan pada insang, dan Gyrodatylus sp. yang ditemukan pada kulit dan sirip. Sedangkan bakteri hasil identifikasi terdiri atas Aeromonas hydrophila, Acinetobacter sp., Lactobacillus sp., Bacillus sp., Haemophilus sp., Arachnia sp., Cardiobacterium sp., dan Enterobacter sp. Bakteri Lactobacillus sp. dan Bacillus sp. merupakan bakteri yang menguntungkan yang dapat dijadikan probiotik.

Perbedaan yang nyata pada prevalensi patogen antara kontrol dengan perlakuan menjadikan saran agar sebaiknya memelihara atau membudidayakan ikan rainbow dengan menambahkan batu karang ke dalam wadah pemeliharaan sampai diperoleh $\mathrm{pH}$ pada kisaran 8 sehingga dapat meminimalisasi infeksi patogen.

\section{DAFTAR ACUAN}

Alvarez-Pellitero, P. 2009. Report about fish parasitic diseases. http://ressources. ciheam.org/om/pdf/. November 2010.

Amos, K.H. 1985. Procedures for detection and identification of certain fish pathogen. F.H.S. American fish, Soc.Carvelis-Oregon, $114 \mathrm{pp}$.

Aoki, T. 1999. Motile aeromonads (Aeromonas hydrophila). In P.T.K. Woo and D.W. Bruno (eds.) Fish Diseases and Disorders. Vol.3 : Viral, Bacterial and Fungal Infections. CAB int'l, p. 427-453.

Austin, B. \& Austin, D.A. 1999. Bacterial fish pathogens. Disease of farmed and wild fish. $3^{\text {rd }}$ edition. Springer-Praxis series in aquaculture $\&$ fisheries. Chichester. UK, $457 \mathrm{pp}$.

Betty. 2009. Common freshwater fish parasites pictorial guides. http://thegab.org/Illnessand-Treatment/common-freshwater-fishparasites-pictorial-guides.html. November 2010.

Cowan, S.T. 1974. Manual for the Identification of Medical Bacteria. Great Britain : Cambridge University Press, 250 pp.

Dogiel, V.A., Petrushevski, G.K., \& Polyanski, Yu.l. 1958. Parasitology of fishes. Translated by Kabata, Z. PhD. Leningrad University Press, 384 pp.

Floyd, R.F. \& Peggy, R. 1991. Ichthyophthirius multifiliis (white spot) infection in fish. http://edis.ifas.ufl.edu/FA033. November 2010. 
Frerich, G.H. \& Millar, S.D. 1993. Manual for the isolation \& identification of fish bacterial pathogens. Pisces Press. Stirling. 60pp.

Graham, D. 2009. Ulcer disease of ornamental fish. http://www.afbini.gov.uk/adds fishulcerdiseasedec05.pdf. November 2010.

Gurr, E. 1956. A Practical Manual of Medical and Biological Staining Technique, Leonard Hill Ltd, London, $373 \mathrm{pp}$.

Hawking, J.H., Smith, L.M., \& Le Busque, K. 2006. Identification and Ecology of Australian Freshwater Invertebrates. www.mdfrc.org. au/bugguide. November 2010.

Hoffman, G.L. 1967. Parasites of North American Freshwater Fishes. http://onlane library.wiley.com/doi/10.1111/j.15507408.1986.tb05628.x/pdf. November 2010.

Jones, D. 2008. Anchor worms and fish lice. KHA, Texas. Mid atlantic koi. 29-31 p. http:/ /www.makc.com/AnchorWormsFishLice. pdf.

Kadarusman, Pouyaud, L., Slembrouck, J., \& Sudarto. 2007. Studi Pendahuluan Diversitas Jenis, Habitat, Domestikasi dan Konservasi Ex-Situ Ikan Rainbow; Melanotaenia di Kawasan Vogelkop Papua.APSOR-IRDLRBIHAT. Tidak dipublikasikan, $12 \mathrm{hlm}$.

Lewbart, G.A. 2008. Important fungal and parasitic disease of ornamental fish. http:// www.michvma.org/documents / MVCProceeding2008/Lewbart4.pdf. November 2010.

Lewbart, G. 2009. Important infectious diseases of ornamental fish. http://www.vin.com/ VINDBPub/SearchPB/Proceedings / PR05000/PR00336.htm. November 2010.

Gardenia, L., Koesharyani, I., Supriyadi, H., \& Mufidah, T. 2010. Aplikasi deteksi Aeromonas hydrophyla penghasil aerolysin dengan menggunakan polymerase chain reaction (PCR). Prosiding Forum Inovasi Teknologi Akuakultur, hlm. 877-883.

Musa, N., Wei, L.S., Shaharom, F., \& Wee, W. 2008. Surveillance of bacteria species in diseased freshwater ornamental fish from aquarium shop. World Appl. Sci. J., 3(6): 903908.

Noga, E.J. 2000. Fish disease diagnosis and treatment. lowa State University Press. United States of America, $367 \mathrm{pp}$.
Piazza, R.S., Martins, M.L., Guiraldelli, L., \& Yamashita, M.M. 2006. Parasitic diseases of freshwater ornamental fishes commercialized in Florianopolis, Santa Catarina, Brazil. B. Inst. Pesca, Sao Paulo, 32(1): 5157.

Pollard, D.R., Johnson, W.M., Lior, H., Tyler, S.D., \& Rozee, K.R. 1990. Detection of the aerolysin gene in Aeromonas hydrophila by the polymerase chain reaction. J. of Clinical Microbiology, p. 2477-2481.

Reed, P., Floyd, R.F., \& Klinger, R.E. 1996. Monogenean Parasites of Fish. http://edis.ifas. ufl.edu/FA033. November 2010.

Smith, S. \& Schwart, M. 2009. Commercial fish $\&$ shellfish technology fact sheet, dealing with Trichodina and Trichodinella-like species. http://www. Ext.vt.edu. November 2010.

Sudarto, Kadarusman, \& Pouyaud, L. 2007. Project FISH-DIVA, Freshwater Fish Diversity in South East Asia. Biannual Report 2006-2007. LORIBIHAT-APSOR-IRD. FISHDIVA Program, p. 69-94.

Sudarto \& Nur, B. 2008. Biodiversitas Ikan Pelangi (Rainbow Fish) Asal Indonesia Bagian Timur dalam Suriyadi, H., A. Hanafi, A.H. Kristanto, Chumaidi, A. Mustafa, Imron, \& I. Insan. Teknolgi Perikanan Budidaya. Pusat Riset Perikanan Budidaya, hlm. 455462.

Takashima, F. \& Hibiya, T. 1995. An atlas of fish histology. Normal and pathological features. $2^{\text {nd }}$ edition. Kaodansha published. Tokyo University of Fisheries. Japan, 193 pp.

Taufik, T. 2008. Ekspor ikan hias Indonesia turun http://www.export-import-indonesia. com/blog/ekspor-ikan-hias-indonesiaturun.html. November 2010.

Untergasser, D. 1989. Handbook of Fish Disease. T.F.H. Publ. Inc., 160 pp.

Weaver, D.E. 2009. Importation of diseases with ornamental fish: problem and risk analysis. http://www.scientifichatcheries.com/ Importation. HTML. November 2010.

Yuasa, K., Panigoro, N., Bahnan, M., \& Barkat, E. 2002. Panduan Diagnosa Penyakit Ikan. BBAT Jambi. DKP, $76 \mathrm{hlm}$. 